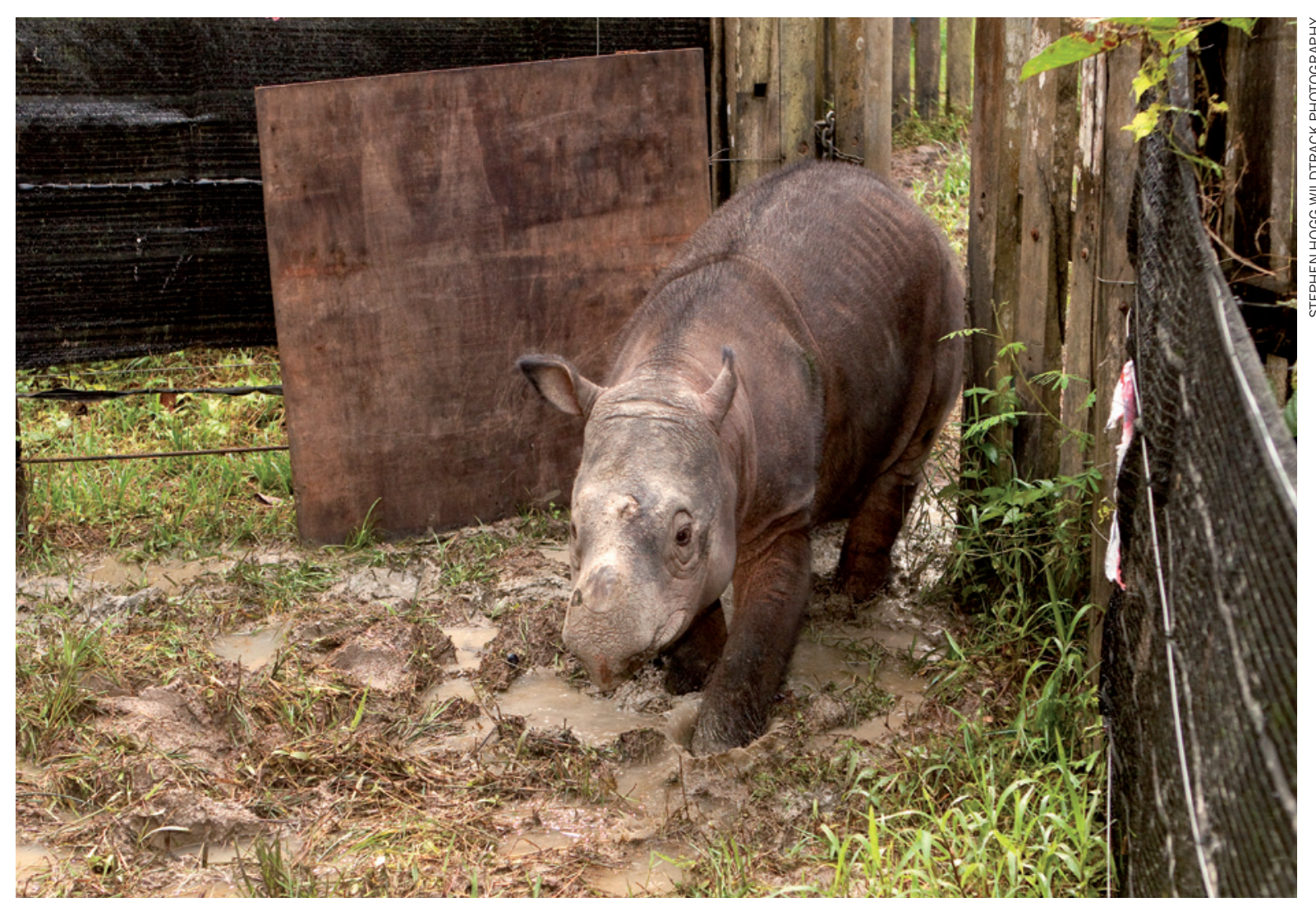

\title{
Sex and the single
}

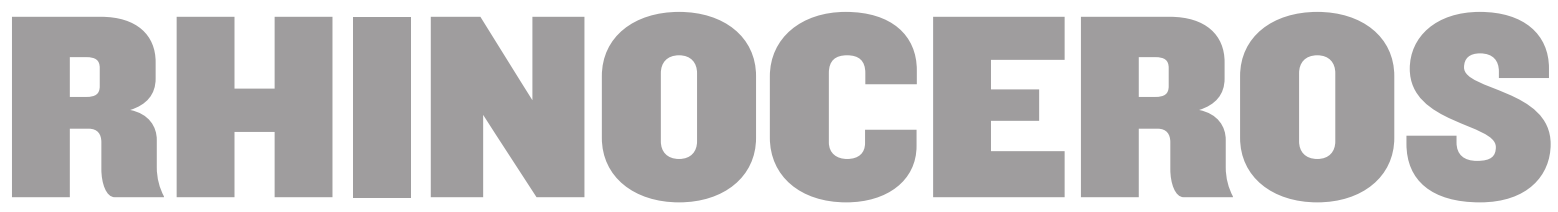

Conservationists are taking heroic measures to restore the fertility of a three-footed Sumatran rhino. But some ask whether this is the right way to save an endangered species.

\section{BY HENRY NICHOLLS}

$\mathrm{F}$ irst, the vet inserts his arm in a shoulderlength plastic glove. Next, he grips an ultrasound probe and slides both arm and probe deep into the rectum of a 500-kilogram rhinoceros. All eyes of those present, including his, are on the ultrasound image on the laptop monitor nearby. As the vet moves the probe over the animal's intestinal wall, her uterus comes into view on the screen. Even to the untrained eye, it is clear that there is something seriously wrong: marble-sized cysts fill the space where there should be a smooth uterine lining. As if in acknowledgement of the fact, the rhino lets out a doleful moan.
This is Puntung, a Sumatran rhinoceros that is missing a foot as well as a working uterus. Yet the future of this species in Malaysian Borneo may rest on the hairy shoulders of this singular beast. If she is ever to reproduce, she will need Thomas Hildebrandt and his veterinary team from the Leibniz Institute for Zoo and Wildlife Research (IZW) in Berlin to rescue her womb - and then push the boundaries of rhino assisted-reproduction to new extremes.

According to the latest best guess, only 200-300 Sumatran rhinos (Dicerorhinus sumatrensis) may be left in the wild, split between three territories in southeast Asia: the Indonesian
Puntung, a female Sumatran rhino, is part of captive breeding efforts in Malaysia. 
island of Sumatra, Peninsular Malaysia and the state of Sabah in Malaysian Borneo (see 'The remaining rhinos'). This perilous situation is a result of a devastating combination of habitat loss (mainly to create lucrative oil-palm plantations) and poaching (to feed the black market for rhino horn). Conservationists say that the species' small, fragmented population is now the biggest threat to its survival ${ }^{1}$, with animals so sparsely distributed that they are simply unable to meet each other to mate. Because females that haven't mated when they are in oestrus can develop problems with their uterus, the rare encounters that do take place often come to naught. At best, rhino mothers take several years between pregnancies - meaning that the birth rate in the wild is unlikely to keep up with poaching and natural deaths.

\section{DRASTIC MEASURES}

This desperate situation has led conservationists in Sabah to a desperate conclusion: that the only way to maintain the rhino population here is to capture as many as possible of the remaining animals - which may number as few as 30 - and subject them to assisted reproductive technology. That includes scrubbing out the uterus of Puntung, and possibly techniques such as in vitro fertilization (IVF) and cloning, the likes of which have rarely been wielded in the name of conservation. "Either we give up or we try to make every fertile rhino contribute to the future of this species," says John Payne, executive director of the Borneo Rhino Alliance (BORA) in Kota Kinabalu, Sabah. "The best way to do that is to bring them into fenced, managed facilities."

Such a drastic attempt to rescue a highly endangered species has precedents. Conservationists have, through heroic efforts, wrestled species such as the Arabian oryx (Oryx leucoryx), the black-footed ferret (Mustela nigripes) and the California condor (Gymnogyps californianus) back from the brink of extinction by bringing all the remaining animals together, using artificial insemination to spread sperm and maximize genetic diversity, and keeping offspring alive through roundthe-clock husbandry.

In the case of the Sumatran rhino, however, some conservationists worry that without a long-term strategy for reversing the environmental pressures that are killing them off, captive breeding alone can never restore the wild population. "It's not a plan unless you've mitigated the threats that wiped them out in the first place," says Alan Rabinowitz, chief executive of the wild-cat conservation group Panthera in New York city. Others are uncomfortable with throwing so much money and effort at a single species - a single animal, in Puntung's case - when the chances of success are so slim. "One of the biggest challenges facing conservation today is our inability to step back and admit that there are animals that would take a little bit less work and a little bit less money but have the potential to survive for their genetic diversity into the future," says John Fraser, chief executive of the New Knowledge Organization in New York city, a think tank and advocate of a triage response to species conservation. "They may not be as charismatic, but quite frankly we have to admit that some species are not going to make it and it's really, really sad."

Puntung got her name, which translates roughly as 'Stumpy', in 2007, when a ranger in the Tabin Wildlife Reserve in eastern Sabah came across her distinctive three-footed tracks. It is thought that she must have lost her foot to a poacher's snare as a calf, and that her mother nursed her back to hobbling fitness. "If she had been even two years of age, the wound that she has would not have healed over," says Zainal Zahari Zainuddin, BORA's field manager, on-site vet and the person closest to Puntung.

In April 2010, the Sabah Wildlife Department and BORA began a joint operation to catch her. It was the first push in an effort to bring as many as possible of Sabah's remaining rhinos into captivity. But it was only after 20 frustrating months that she finally walked into a trap. On Christmas Day 2011, a helicopter airlifted Puntung to her current home in a temporary captive facility within the reserve. Payne estimates that the entire operation, including the cost of hiring the helicopter and constructing her enclosure, set BORA back more than US\$250,000.

With Puntung apparently in her reproductive prime, and with a lone male called Tam in residence since 2008, there was hope that the pitter-patter of tiny rhino feet might soon follow. It was something of a setback, then, when ultrasound scans carried out by Hildebrandt and his team in February showed that Puntung's uterus was riddled with cysts that would make any full-term pregnancy near impossible. Her ruptured hymen suggests an explanation. "We think she must have mated in the wild, got pregnant, but with her handicap was unable to sustain the fetus and it died in utero," says Hildebrandt, who specializes in the assisted reproduction of endangered mammals and has been involved with Sabah's rhinos since 2004. The failed pregnancy led to the cysts. "Such pathology is not uncommon in rhinos," Hildebrandt says, "but is rarely this bad."

A decade ago, this might have been the moment to give up. But reproductive medicine has advanced at such a pace that there are still options for Puntung, particularly as she seems to be relatively young - with as many as 10 years of reproductive life ahead of her - and her ovulatory cycle seems to be normal.

At the end of March, Hildebrandt and two of his IZW colleagues flew back to Sabah on a uterine-rescue mission, accompanied by huge suitcases filled with veterinary paraphernalia: green scrubs, anaesthetics, antibiotics, drips, probes, a carbon-fibre catheter patented by Hildebrandt and his colleagues for the insemination of rhinos, and a gun case containing a 2-metre-long video endoscope tailor-made to fit Puntung's reproductive tract.

Once in the Tabin reserve, the IZW vets, BORA staff, including Payne and Zahari, and the Sabah Wildlife Department's chief field vet assemble in a hut beneath the glare of fluorescent strip lighting to be briefed on the impending procedure. If all goes to plan, explains Hildebrandt, he will insert the endoscope into Puntung's uterus and attempt to lance some of the cysts, particularly ones that are preventing

\section{THE REMAINING RHINOS}

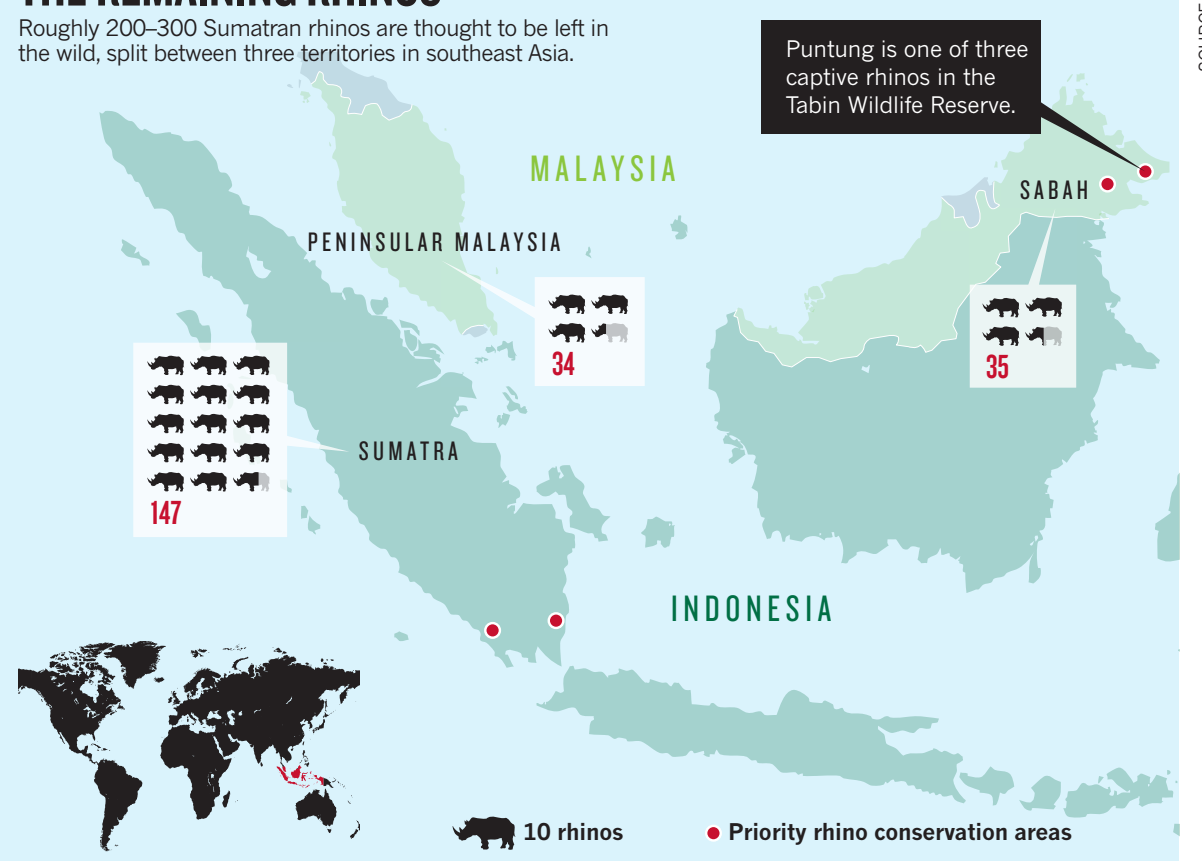


sperm from entering the oviducts. That might smooth the way for insemination - either artificially or by Tam - followed quickly by the collection of fertilized embryos before they implant. By repeating the procedure every month for the rest of her reproductive life, it might be possible to harvest as many as 100 embryos, freezing them in liquid nitrogen to be implanted into surrogate females in years to come.

With everyone's questions answered, Hildebrandt and his team wheel their equipment out into the rain. The croak of thousands of invisible amphibians falls suddenly silent as the vets pass by on the way to Puntung's enclosure.

\section{RARE BREED}

Past efforts to breed Sumatran rhinos in captivity have been spectacularly unsuccessful. it looks like [captive breeding] is a serious need for the species," says Terri Roth, director of the zoo's Center for Conservation and Research of Endangered Wildlife, which works closely with Indonesia's Sumatran Rhino Sanctuary in Way Kambas National Park.

There are also signs of greater cooperation between captive facilities. At a March meeting of the Sumatran Rhinoceros Global Management and Propagation Board in Jakarta, all parties put their signature to a "Letter of Intent for Collaboration". This puts aside past taxonomic differences, and acknowledges that all captive animals should be part of a single, globally managed breeding programme and that captive facilities will share sperm and embryos "based on availability and need". Testifying to this new entente cordiale, the Sabah Wildlife Department has agreed to send semen col-

\section{"WE HAVE TO ADMIT THAT SOME SPECIES ARE NOT GOING TO MAKE IT AND IT’S REALLY, REALLY SAD."}

Between 1984 and 1993, at least 35 wild rhinos were taken into captivity across the region without the birth of a single calf. Zoologists knew little about the reproductive rhythms of rhinos, breeding facilities rarely housed a good mix of males and females, and disagreements over whether the Sabah rhino was a subspecies of the Sumatran rhino meant that there was little cooperation between Indonesia and Malaysia and even between Peninsular Malaysia and Malaysian Borneo. The fruitless attempts frustrated some conservationists, including Rabinowitz. In a frank essay ${ }^{2}$ published in 1995, he accused the conservation community of "helping a species go extinct" by placing too much emphasis on captive breeding of the Sumatran rhino at the expense of "the more difficult job of protection and management in the field".

The case for captive breeding may be stronger now. "In Peninsular Malaysia, the species is either extinct or about to go extinct," Payne says. And in Sabah "the numbers are so low, that no method exists to find out how many are now left". In the 1980 s, when he was working in what is now the Tabin Wildlife Reserve, he recalls coming across rhino footprints within a matter of days in the field. "At best we can now find old rhino footprints perhaps once or twice per year," he says.

Meanwhile, captive breeding has scored some successes. In 2001, Cincinnati Zoo announced $^{3}$ the first Sumatran rhino to be born in captivity since 1889 . The same star breeding pair, on loan from Indonesia, went on to produce two more calves. "We had to learn how to feed this species, we had to learn about its reproductive physiology, and thank goodness we started as early as we did because now lected from Tam to Cincinnati Zoo to attempt artificial insemination of a young female when she reaches sexual maturity. But with just ten animals in captivity worldwide - three at Cincinnati Zoo, four at the Sumatran Rhino Sanctuary and three in the Tabin reserve - more animals will need to be caught in Sumatra to establish a viable captive population, says Roth. "We need to pull them in and manage them intensively and make sure as many of them breed as possible," she says.

Rabinowitz acknowledges the greater urgency for captive breeding, but disputes whether the data on population size, sex ratio

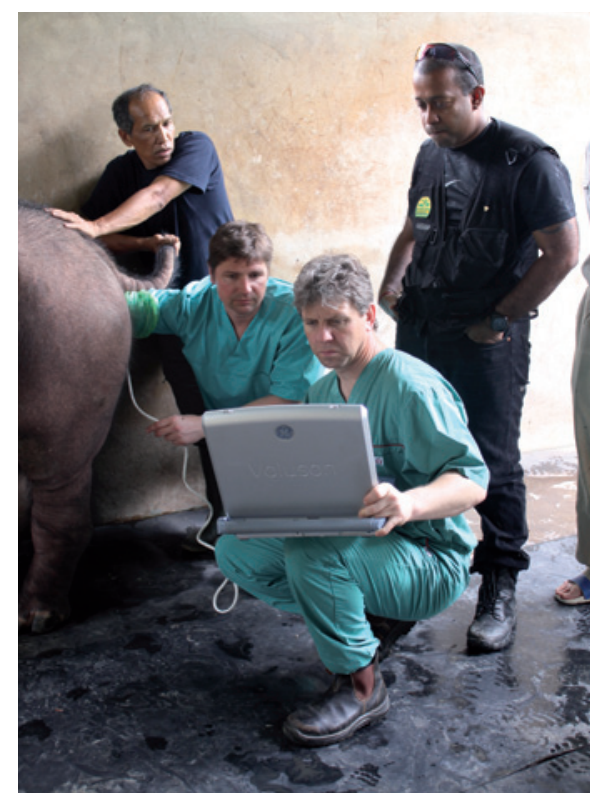

Thomas Hildebrandt (front) and his team carry out an ultrasound examination on Puntung. and breeding success in the wild are good enough to say that wild populations are in terminal decline or that captive breeding - "an absolute last resort", he says - is the only option. "When you lack information and just say there's no hope, then you're really writing the end of the book."

\section{OPERATION UTERUS}

Before her ultrasound scan, the unsuspecting Puntung is lured into a small pen by a bucketful of diced bananas. Hildebrandt's colleague Frank Göritz loads a syringe with a dose of sedative calculated to send her into a standing anaesthesia, then reaches through the bars to plunge the needle through her sparsely haired hide. Within seconds, she has relaxed into a sling, which supports her bulk and makes it easier to insert an endoscope into her uterus than if she were lying down.

When Robert Hermes, the third member of the team, slides his gloved arm into Puntung's rectum she barely flinches. She has undergone a period of intensive coaching to tolerate medical procedures. Now, it is impossible to tell that she's undergoing a transrectal ultrasound scan, were it not for the vet squatting at her rear.

Almost an hour later, however, the first signs of stress are showing - though not from Puntung. The ultrasound is over and Hildebrandt is struggling to insert the carbon-fibre catheter into her uterus. On his knees, with his right arm deep in her vagina and his cheek brushing up against her buttocks, his face is a picture of concentration and his scrubs are darkening with sweat. Puntung's cervix, tightly constricted owing to the phase of her menstrual cycle, is proving a serious obstacle to the catheter.

Eventually, Hildebrandt triumphs and is able to flush out the uterus with a sterile cell medium, which will be tested for any underlying infection. With the cervix so narrow, there is no hope of moving on to the bigger-bored endoscope, but before Hildebrandt removes the catheter he injects a highly concentrated penicillin solution. This will destroy any pathogenic bacteria, and is so concentrated that it may actually strip away some of the lining and cysts, possibly making it easier to attempt fertilization and embryo collection. Hildebrandt has successfully used this approach to boost the fertility of two tigers and a leopard ${ }^{4}$. If it doesn't work, the favoured next step is to carry out a similar procedure at a future date, but to inject a more caustic chemical such as kerosene to attack the cysts. This carries a risk. The team has to make sure that the treatment "is not so aggressive that it destroys the uterus", Hildebrandt says.

Before the vets call it a wrap, there is still time to take a cast of Puntung's stump, which will be used to fashion a prosthetic foot. This will allow her to move around with greater comfort. If she ever gets a chance to mate with Tam, the foot will also be handy for supporting his weight on her back during the half-hour encounter. 


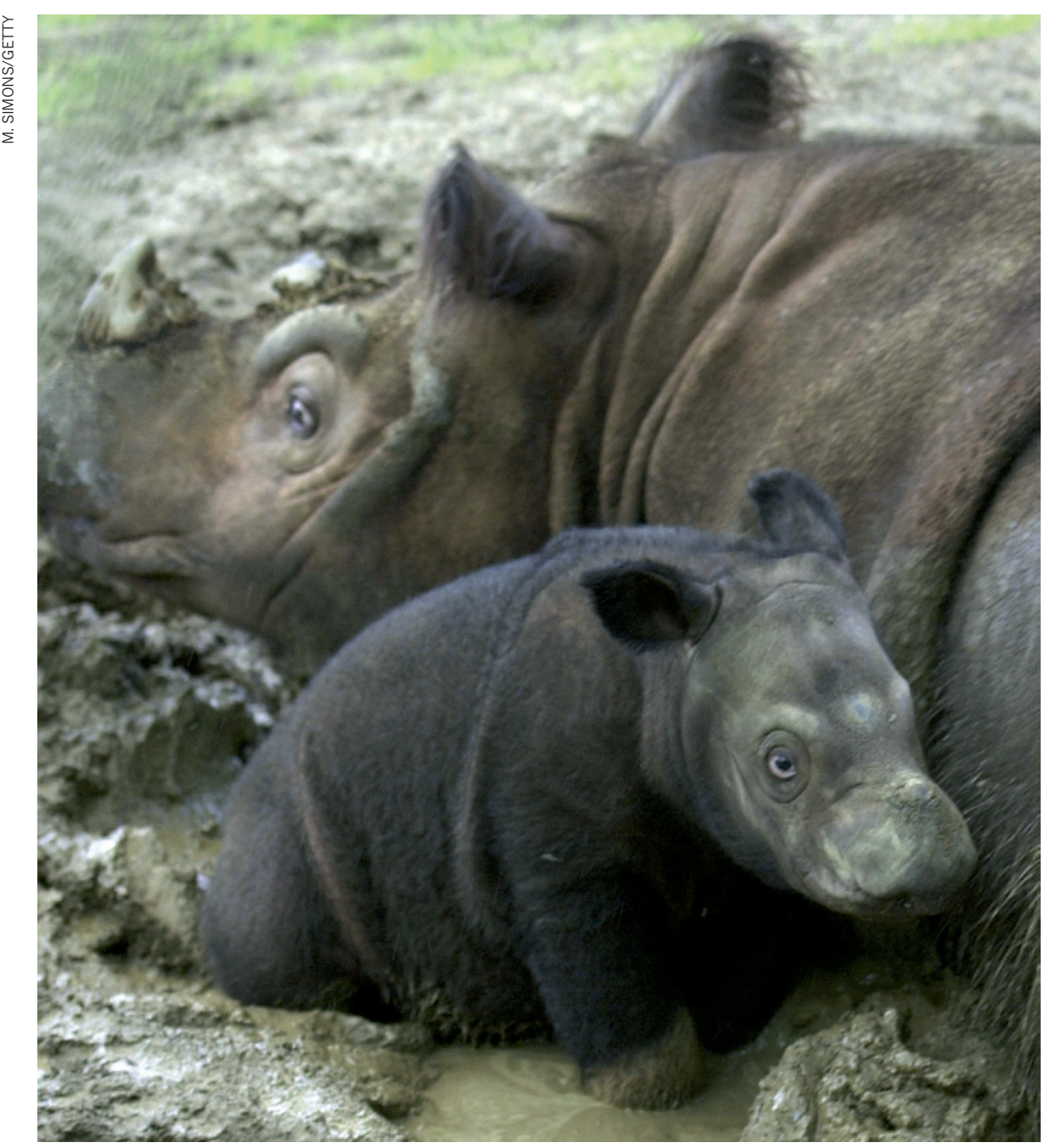

At Cincinnati Zoo, Emi lies back with her calf, one of only three Sumatran rhinos born in captivity since 1889.

Even if embryo collection proves unsuccessful, it might not be the end of the road for Puntung. It should be possible to collect immature eggs, by inserting a fine needle through the wall of her rectum and into her ovaries. The challenge is getting them to mature and fertilize in vitro. The IZW vets have attempted this with white and black rhinos ${ }^{5}$. They obtained 29 eggs and managed to fertilize one, but the embryo did not progress beyond the four-cell stage. The only attempt to harvest eggs in Sumatran rhinos - from Cincinnati Zoo's star female just after her death in 2009 - was unsuccessful ${ }^{6}$.

There are other, more futuristic options. In theory, Puntung could be cloned, taking a nucleus from one of her cells and injecting it into an egg stripped of its own DNA. That rhino eggs are in short supply needn't be a problem, says Pasqualino Loi, a reproductive biologist at the University of Teramo in Italy, who, more than a decade ago, used domestic sheep as a source of eggs and surrogates to clone an endangered sheep relative, the mouflon ${ }^{7}$. "Play around," he suggests. "Inject some rhino mitochondria and a nucleus into a horse egg." It's just possible, says Loi, that it could result in a viable embryo that could be successfully nurtured to term by a surrogate mare.

Pursuing another strategy, scientists at San Diego Zoo in California last year showed that banked tissue from the almost extinct northern white rhino (Ceratotherium simum cottoni) could be induced to form a line of pluripotent stem cells, capable of forming many tissues ${ }^{8}$. It's possible that these cells could be used to generate working gametes, using the same techniques that have produced sperm in mice ${ }^{9}$.

Hildebrandt advocates natural mating before attempting IVF or other reproductive technologies, but he is already starting to bank rhino tissue. With part of a $€ 500,000$ (US\$640,000) grant from the German Federal Ministry of Education and Research awarded in December 2010, he established a cryo-bank facility in Kota Kinabalu. In it are fibroblasts from Tam and Gelogob, a blind and elderly female rhino in captivity at the Tabin Wildlife Reserve. Cells from Puntung will join them shortly. "If we

\section{DNATURE.COM}

Watch a video

of Puntung's

operation at:

go.nature.com/bezucu can't find the solutions, then people after us can," Hildebrandt says. "We have the responsibility to make it available to the next generation."
Yet the chance that such technologies will succeed in a species like the Sumatran rhino, whose basic biology is still poorly understood, seems remote. Roth says that tissue banking "is not a priority compared with some of the other issues we're up against". And the Indonesian government's action plan for rhino conservation, spanning 2007-17, contains no mention of tissue banking ${ }^{10}$.

Money, too, is in short supply. It is a stinging irony that by far the biggest donor to BORA is the Sime Darby Foundation, the philanthropic arm of the Sime Darby Group, based in Kuala Lumpur, one of the world's biggest producers of palm oil, the crop that led to the destruction of much of the rhino's rainforest home. It has committed a further $\$ 2$ million to fund BORA's operations up to 2015 and after that the charity is on its own. "This is a bit of a worry," admits Payne. Hildebrandt says that his grant from the German government has expired. He knows that he needs some demonstrable success with Puntung to get more. "If we are not successful in the next few months, then I think the programme is over," he says.

Other conservation biologists argue that it already is. Even if assisted reproductive technologies do prove possible, Fraser asks how long the new animals would survive. "My concern is that [the Sumatran rhino's] future viability as a species on this planet and the future viability of any offspring is really in question because the habitat just isn't there. So I question the priority setting, although I can certainly understand the emotional state of those invested in saving the animal."

Puntung, of course, is oblivious to the emotions and the debate. The operation over, Göritz injects her again to reverse the effect of the anaesthesia and within minutes she is out of the sling. Zahari enters the enclosure and unfurls a hose to spray her down. It's a ritual she clearly enjoys, raising her neck to meet the droplets of water as they rain down.

Puntung can savour a few weeks of rest and bananas, before science's next assault on her infertility.

Henry Nicholls is a freelance journalist based in London. His most recent book is The Way of the Panda.

1. Ahmad Zafir, A. W. et al. Oryx 45, 225-233 (2011).

2. Rabinowitz, A. Conserv. Biol. 9, 482-488 (1995).

3. Roth, T. L., Bateman, H. L., Kroll, J. L., Steinetz, B. G. \& Reinhart, P. R. Zoo Biol. 23, 219-238 (2004).

4. Hildebrandt, T. B. et al. Theriogenology 66 , 1783-1786 (2006).

5. Hermes, R. et al. Theriogenology 72, 959-968 (2009).

6. Stoops, M. A., Bateman, H. L., Campbell, M. K. \& Roth, T. L. J. Zoo Wildl. Med. 42, 723-726 (2011).

7. Loi, P. et al. Nature Biotechnol. 19, 962-964 (2001).

8. Ben-Nun, I. F. et al. Nature Methods 8, 829-831 (2011).

9. Hayashi, K., Ohta, H., Kurimoto, K., Aramaki, S. \& Saitou, M. Cell 146, 519-532 (2011)

10. Ministry of Forestry of the Republic of Indonesia Strategy and Action Plan for the Conservation of Rhinos in Indonesia (Jakarta, 2007); available at go.nature.com/ssdt2t. 